Matgorzata LisiowSKA

National Veterinary Research Institute, Puławy, Poland

m.lisiowska@piwet.pulawy.pl

DOI: $10.5604 / 17307503$

JOURNAL OF MODERN

IRENEUSZ SŁAWOMIR SOŁTYSZEWSKI

SCIENCE TOM 4/35/2017,

University of Warmia and Mazury, Olsztyn, Poland

ireneusz.soltyszewski@uwm.edu.pl

JóZEF SZAREK

Department of Pathophysiology, Forensic Veterinary

Medicine and Administration University of Warmia

and Mazury in Olsztyn, Poland

szarek@uwm.edu.pl

Mariusz ZBigniew FELSMANN

Centre for Veterinary Sciences Nicolaus Copernicus

University, Toruń, Poland

felsmann.mariusz@wp.pl

\title{
VETERINARY INSPECTION IN THE FOOD SAFETY SySTEM In Poland
}

\begin{abstract}
Food safety is secured with its accurate quality and therefore, food should be adequately controlled with effective measures. The objective of this paper is to analyse the activities of the Veterinary Inspection (VI) while presenting its role and operational efficacy in the domain of food safety and quality. The analysis has demonstrated that the VI executes animal health protection and veterinary protection of public health. The authority is obliged to supervise the safety of animal-origin food products at the stages of production, marketing and direct sales. Its control measures also cover the health of reproduction animals and its health quality. The Veterinary Inspections also cover animal protection regulations, rules for animal identification and registration, and the transport of animals. Furthermore, the body imposes veterinary requirements on animal farms. It has been demonstrated that the VI also monitors illegal substances, chemical, biological and medical product residues as well as radioactive contamination in animals and poultry, and the trade and volumes of veterinary medicinal products. The competencies of the VI enable the authority to effectively
\end{abstract}


execute its statutory responsibilities. However, the domain in which the VI operates does not include all business entities of the food chain. This creates challenges for the comprehensive supervision of food production and distribution and suggests that the currently proposed concept of the National Food Safety Inspection will increase the efficacy of control measures on this new body in comparison with the VI.

KEYWORDS: Veterinary inspection, law, food safety, public health, diseases of animals

\section{INTRODUCTION}

The Veterinary Inspection (VI) has a prominent role among specialised and dedicated authorities involved in public health protection issues. This body focuses its activities on the food safety and hygiene domain. The VI competencies include both the elimination of infectious diseases of animals and the surveillance in abattoirs (over animals and meat). The VI monitors the health quality of animal-origin food products, such as sanitary conditions during collection, production and storage as well as the health quality of animal feedstuffs.

The objective of the paper is to discuss the activities of VI with a special emphasis on their role and position in the system of public health protection and an assessment of operational efficiency in relation to the current legal regulations. The paper will also outline the concepts and assumptions of planned systemic changes in the field of food safety and quality control.

\section{ACTIVITIES AND STRUCTURE OF THE VETERINARY INSPECTION}

The VI Act of 29 January 2004 (consolidated text: Dz.U. of 2016, item 1077 as amended) contains a catalogue of tasks that cover two main activities, ie animal health protection and veterinary protection of public health. The detailed scope of tasks features the following: prophylaxis and elimination of infectious diseases of animals and zoonotic diseases, slaughterhouse examinations (of animals and animal-origin products), veterinary border control and cooperation with the other inspections involved in public health protection. Within this task scope, VI manages the exchange of information between the EU bodies. The authority is obliged to supervise the safety of animal-derive foodstuffs, including production, marketing and direct sale stages. 
The scope of controlling assigned to the VI includes the health of reproduction animals and health quality of biological materials, hatching poultry eggs and turnover and quantities of veterinary medicinal products. The surveillance activities of VI are of special importance in relation to animal protection regulations, identification and recording of animals, animal transport and veterinary requirements on production animal farms. Moreover, the VI ensures, from the animal welfare perspective, that the animal protection regulations, identification and recording of animals, animal transport and veterinary requirements on production animal farms are observed. The Veterinary Inspection is also involved in monitoring the use of illegal substances, the residues of chemical, biological and medicinal products, and radioactive contaminations in animals, their body secretions and excrements, in tissues or organs, in animal-derived products, in drinking water for animals, and in animal feeding stuff. Furthermore, VI supervises the production, marketing and use of feeds and feed supplements in animal nutrition, genetically modified organisms destined for use in animal feeds, genetically modified feeds and cross-border movement of genetically modified organisms destined for use in feedstuffs.

The above-mentioned activities are pursued by the VI arms that include: the Chief Veterinary Officer (CVO) and provincial, district and border veterinary officers who manage the veterinary inspection offices at respective levels. The CVO is appointed and dismissed by the Prime Minister upon the request of the Minister of Agriculture who issues regulations and thereby assigns the status of the Chief Veterinary Inspectorate. The Sanitary and Epizootic Board and the Laboratory Board are consultative and advisory bodies to the CVO.

According to art. 13.1 CVO competencies among encompass setting new directions for VI and coordinating and controlling the progress of task completion by provincial, district and border veterinary inspectors. The CVO develops the national elimination programs for notifiable infectious diseases of animals and zoonotic diseases, operates control tests for infections in animals, monitors zoonotic diseases and zoonotic pathogenic microorganisms subject to compulsory surveillance, monitors illegal substances, chemical, biological and medicinal product residues and radioactive contamination 
in animals. The body collects and analyses the data on all detected cases of dangerous plant- and anima-derived food and feed that are subject to the expertise of VI, the Main Inspectorate of Plant Health and Seed Inspection, the Agricultural and Food Quality Inspection and the Trade Inspectorate. The CVO secures the reserve pool of vaccines, biopreparations, and biocidal products as well as other means essential for diagnosing and eliminating the infectious diseases of animals, including zoonotic diseases and the monitoring of zoonotic diseases and their aetiological agents and associated resistance to antimicrobial in animals, in animal-origin products and feedstuffs.

Membership in the EU implies that the CVO is responsible for ensuring that the EU-binding veterinary legal regulations are observed. Cooperation with the authorities of the EU members and with the European Commission consists in releasing and exchanging information on how the veterinary regulations are observed and on any breaches thereof and in transferring information on veterinary-related agreements or arrangements settled with the third countries.

The provincial veterinary officer is a body of the provincial veterinary administration; the officer is overseen by the CVO in the field of sanitary and epizootic safety over a respective area. The competencies of the provincial veterinary officer include outlining the pathways for activities, issuing instructions setting the conduct for district veterinary officers within the province, and controlling how the veterinary inspection activities are accomplished. The body issues commands on undertaking specific actions for district veterinary officers; it demands feedback information from them, performs analyses and evaluates epizootic situations, animal-origin food safety, animal feedstuff safety and veterinary requirements for their production. It also develops the provincial programs on monitoring zoonotic diseases and zoonotic pathogenic agents.

According to the ordinance No 1 of the Minister of Agriculture and Rural Development of 2 March 2010 (Official Journal of the Ministry of Agriculture and Rural Development of 11 March 2010) the structure of a provincial veterinary inspectorate includes the following units: animal health and protection unit, food, feed and animal by-product safety unit, pharmaceutical surveillance unit and a veterinary hygiene office. 
The district veterinary officer is a part of the VI and operates accordingly at a district level. District veterinary inspectorates, analogically to the provincial and border inspectorates, are public administrative entities.

According to the law of August 27, 2003 on veterinary border control (uniform text: Dz.U. of 2017, item 970) the border veterinary officer is directly supervised by the Chief Veterinary Officer; within the scope of their competences, the officer conducts inspection of animals, animal-origin products and feeds imported from the third countries to the EU and animaderived products and animals transited via the EU. Moreover, the officer supervises the external security of the EU and Poland borders in relation to the risks of infectious disease and other noxious factors; the officer controls documents, identifies commodities and takes part in the laboratory and sensory controls. The body cooperates with the customs office to ensure the correct control of animal, product, feed, and medicated feed parcels as well as domestic animals accompanying travellers and transported for noncommercial purposes, animal-derived products destined for consumption on an individual basis, imported from the third countries in luggage, animals accompanying travellers and transported for non-commercial purposes and subject to control specified in the animal protection regulations and laws on the elimination of infectious diseases of animal. The border veterinary officer and customs authorities exchange the appropriate documentation. They provide mutual help to correctly identify parcels during control procedures. The customs authorities and VI bodies can undertake, in justified cases, common control measures to control the entities that operate customs bonds, bonded warehouses or warehouses situated in free zones and inform each other on decisions affecting the entities under control (Rudy, Kapusta, 2005, p. 465).

\section{MilitARY VETERINARY INSPECTION}

The Polish Army Veterinary Officer, being the supervisor of the Veterinary Unit in the Polish Army, is responsible for executing the duties and tasks associated with Veterinary medicine in the areas and in relation to the organizational bodies under the authority of the Minster of National Defence and the armed forces units of foreign countries located in such areas. The competencies of the Polish Army Veterinary Officer or an authorized 
officer, according to the Regulation of the Minister of Agriculture and Rural Development of 28 October 2004 (Dz.U. 2004, No. 245, item 2462), include potential involvement in the border control, carried out by the border VI units, of vehicles used for animal transportation or animal-origin products destined to satisfy the needs of the Polish Army and the control of plants supplying the Polish Army in animal-origin products or attempting to become such a supplier. The Military Veterinary Inspection cooperates with the VI, Military Sanitary Inspection, National Sanitary Inspection, health services in the units under authority of or supervised by the Minister of National Defence and with the veterinary services and health services of the armed forces units of foreign countries located in Poland in the following fields of activity: animal protection, elimination of infectious diseases of animals and safety of animalorigin products to the benefit of the public health.

\section{FORMS OF ACTIONS OF THE VETERINARY INSPECTION}

For the veterinary bodies, the main form of action consists in issuing administrative procedure acts, which serve the VI to execute its basic duties in the domain of health protection of animals and protection of possessions against economic losses resulting from infectious diseases of animals and control of business and economic activities that are associated with animals or food in the scope of veterinary and sanitary prophylaxis, in its general meaning.

The elimination of infectious diseases of animals is most often associated with the necessity to impose duties (or constraints for using the authorization rights) on the external entities in relation to the public administrative bodies. The measures and actions of sanitary and veterinary prophylaxis are linked to the obligation of making official decisions on granting or refusing to grant certain eligibility or powers to an entity. Such a role requires giving the veterinary regulations, standards and laws a practical form, namely, issuing an administrative procedural act in a situation of an epizootic risk or a risk to the safety of animal-origin products or if it is necessary due to the public health protection or to protect the national economy against losses regulated by art. 18 Act on VI. 
Other functions include issuing certificates, carrying out preventive vaccinations, controlling, developing emergency plans or executing the informative, teaching and educational functions. For instance, a health certificate is a document issued by the veterinary officer and certifying the health condition of an animal or animals and for the commodities imported from the countries outside the EU, it is also meant to be a veterinary certificate as specified in the veterinary border control regulations.

The attestation is a tool used by the veterinary bodies and serves to confirm a certain legal status; this document is issued by the district veterinary officer. These documents include attestations on the compliance with the minimal hygiene and husbandry standards for animal farming necessary to apply for funding or to receive funding or co-funding from the resources of the European Agriculture Guidance and Guarantee Funds and the European Agricultural Fund for Rural Development (Zimmerman, 2010, p. 95).

The VI activities in the food safety domains originate from the European law and are mainly targeted at determining the scope of official control of conformity with the food and feed laws and the regulations on animal health and welfare. To this end, the control is meant to "compare the actual status with the required status and identifying potential non-adherences and checking the conformity with the mandatory legal regulations" (Jagielski, 2006, p. 12). The official controls may have different forms, such as supervision, monitoring, inspections, verification, audits, sampling and sample testing (Regulation(EC) No. 882/2004). The objective is to determine whether the legal provisions are fully and effectively observed (Boć, 2004, p. 389). When any entity prevents or hinders a veterinary controlling procedure, such conduct may provide a basis for "suspending the business activity of a given entity, especially when the entrepreneur has not taken any remedial actions, such as submitting to a control procedure and they have not allowed the authorised officer onto the premises of a plant (Declaration of the Administrative Court in Rzeszow of 17 December 2014).

The duties of public administrative bodies also involve a form of supervision meant as a satiation in which the controlling authority has the power and means to impact the conduct of supervised bodies and entities. 
The controlling authority can impose conditions on the supervised units provided the regulations provide it with such legal powers (Lang, 1996, p. 35). The basic regulations are detailed in the legal acts. The general provisions of legal acts can be further detailed and defined in administrative executive acts and, thereby, the regulation over controlling and supervising is graded in terms of specificity and accuracy (Boć, 2004, p. 234). The supervision of animal-origin products is an example of such function carried out by the VI. The veterinary inspection also supervises the use of animals for experimental and teaching purposes, though the legislative pathway for such authorization is relatively long (Babińska et al., 2007, p. 243-253).

Another form of the VI's activities involves issuing instructions, performing analyses and evaluation of epizootic situations and developing the national programs for the elimination of notifiable infectious diseases of animals and zoonotic diseases, for example, the plan to eradicate Aujeszky's disease (Dz.U. 2015, item. 189).

The Veterinary Inspections fulfils the functions typical of the public administrative bodies to execute the tasks related to the public health protection. Such functions are of an command nature and are carried out in the form of administrative police, a controlling body and a supervising authority. In such circumstances, the VI has powers often giving it the right to interfere in citizens' rights and freedom.

The discussed catalogue of the VI's activities represents only a part of the tasks this authority is responsible for. The authors agree with the view expressed by J. Dobkowski that "the statutory list of tasks assigned to administrative police whose local branches constitute, in fact, inspection and guardian units is not exhaustive, but is only exemplary in nature. The lists of tasks usually go beyond the domain of administrative police concept" (Dobkowski, 2007, p. 185).

\section{ERADICATION \\ OF INFECTIOUS DISEASES OF ANIMALS}

The essential responsibilities of the Veterinary Inspection involve eradication of infectious diseases of animals, namely, the measures undertaken to detect a given disease and to prevent its further spread, the measures aimed at final eradication of the disease, and the measures associated with washing, 
cleaning and disinfection in a disease zone and repopulation of a farm with animals. Within this field, the VI acts in a multi-faceted way, which requires cooperation with a number of national and local administration authorities (Pejsak, 2016, p. 500-503).

Legislative activities and international cooperation with the EU and World Organization of Animal Health (OIE) are another domain, with the system of activities being tied together by IT tools allowing for the flow of information both in Poland, the EU and in the OIE member countries.

If an infectious disease of animals is suspected, the owner of the animals is, in fact, the first link to initiate the procedure (PRK-3.2013). The owner is obliged to promptly inform the VI or the nearest entity providing veterinary service or a village mayor (mayor or city president). Next, the district veterinary officer immediately undertakes measures to confirm or rule out a given notifiable infectious disease of animals. To this end, the epizootic investigation is the basic tool: this is a procedure aimed at identifying the causes, sources and mechanisms of how the disease spreads. The actions involve history taking, examination of a diseased animal or its cadaver with laboratory methods, and evaluation of collected data and drawing conclusions. A correctly taken epizootic history is the key element of the investigation (Związek, 2011, p. 766-770). When the epizootic risk of an infectious disease of animals is detected or the infectious disease of animals is confirmed, the competent authority for emergency management which receives the notification of a risk situation is the first to initiate the procedure (Dz.U. 2007, No. 89, item 590). This authority promptly informs both the supervising bodies and the one under its authority about the event, giving its evaluation of the current status and information on the actions to be undertaken. The provincial governor/district head, provincial/district veterinary officer, bodies of provincial combined and non-combined administration, local administrative authorities and other entities start executing the individual tasks resulting from the measures and procedures initiated in the case of a potential or existing risk of the infectious disease of animals (epizootics). The responsibilities of the emergency management team are to determine the area on which the infectious disease occurs or on which there is a risk of such disease. Such decision can impose a temporary limitation on the movement 
of people and vehicle, organisation of fairs, exhibitions and mass events. The outcome of the emergency management team's actions is to confirm the eradication of the infectious disease of animals in a given area (Supreme Audit, report, 2016).

The eradication of African Swine Fever (ASF) serves as a practical example of the described action model. This is a viral, infectious disease of the domestic pig and wild boar; the first disease case was identified in Poland in February 2014 in the province of Podlaskie. Until February 2017, there were 202 ASF cases detected in the wild boar and 23 in the domestic pig (Pejsak et al., 2017, p. 255-259). Direct or indirect contact with infected animals is the most common route of infection for animals. Though ASF virus is not dangerous to human health and life, it causes considerable economic losses in the meat industry and animal production sector and results in bans on swine, pork and swine-origin product export and trade. The efficacy of actions undertaken by the veterinary authorities is therefore critical to the elimination of this infectious disease. The measures aimed at eliminating the ASF disease zones that were taken confirm the success of the VI actions (Lisiowska et al., 2011, p. 946-948).

\section{ASSUMPTIONS OF THE PROJECT TO LAUNCH THE NATIONAL FOOD SAFETY INSPECTION SERVICE}

The project to consolidate the authorities responsible for the safety and quality of food is related to the food laws in the EU (Regulation (EC) No. 178/2002). It has been attempted to create a new, uniform and integrated system for food safety and quality control at all stages of production by combining all control and monitor processes throughout the food chain, i.e. "from stable to table". The creation of the National Food Safety Inspection, as a part of non-combined administration under the authority of the Minister of Agriculture and Rural Development, is aimed at combining the Veterinary Inspection, the Main Inspectorate for Plant Health and Seed Inspection, and the Agricultural and Food Quality Inspection and making them one body. Furthermore, the project assumes relocating a part of the responsibilities currently assigned to the National Sanitary Inspection, the Trade Inspection and the Environmental Protection Inspectorate to the scope of the consolidated inspection (Draft Law on National Food Safety 
Inspection of 13.07.2016). According to the project, the responsibilities of the newly-launched inspection will include issues linked to food safety, control over the trade quality of agricultural commodities, animal health protection and eradication of infectious diseases in animals, veterinary supervision of animals and animal-origin products, supervision of identification and registration of animals, production and use of feed and control of genetically modified food. It is assumed that this consolidation will help to optimise resources, improve the organisation and quality of work, create clear control rules and a more efficient system of spending the public funds on the operational activities of the administrative authorities. The reform should also help to eliminate jurisdictional collisions between the recently operating inspections and to eliminate issues resulting from the double subordination of the Veterinary Inspection at the county level. The aspects of increased consumer protection and "an accelerated" response to food market crisis event are likewise. At its initial stage, the project assumed that the new VI would have a vertical, three-stage structure. The local branches will not come, as until recently, under the authority of provincial governor or local administrative bodies. The statutory tasks will be funded within one budget segment, which would help rationalise the expenses and use the resources more efficiently. The VI could then become more effective in its operational activities, e.g. can delegate the employees to another part of the country to perform unplanned tasks in emergency situations. Unfortunately, over time, when work on the new project was progressing, it was decided to reject the concept of the vertical structure of the VI.

As intended by the authors of the draft, the creation of an integrated control system for food safety and quality, encompassing the whole production process, is justified from the content point of view and follows the demand for the efficacy of control measures executed by the public administration bodies. Importantly, the project of legislative changes also generated negative comments indicating a need for substantial modifications and threats both on the national scale and with negative effects on the international cooperation. However, during legislative discussions, the laws were accordingly changed and the act was formed to allow effective execution of tasks in the food safety domain (Position of the National Veterinary and Veterinary Council of 9 March 2017). 


\section{Conclusion}

The role and tasks of the VI are becoming increasingly important in the context of information on the spread of infectious diseases and risks associated with food that is quite often occurring. The control tasks of the VI have been thus linked to a very wide scope of authoritative competencies that apply to other public administrative bodies. These competencies authorise the VI branches to impose, usually via the administrative decisions, different commands and bans that are essential in the public health protection domain. This results in the effective execution of the statutory tasks. The discussed status indicates that the proposed changes, which are aimed at creating the National Food Safety Inspection, will increase the operational efficacy of the new body in comparison with the VI. This thesis results from the fact that under current legal status, the division of competencies between the inspections governing the supervision over the entities involved in the food chain has often generated many misunderstandings and difficulties in specifying the competencies of the individual authorities.

\section{References}

Babińska, I., Szarek, J., Felsmann, M.Z., Kowalski, I.M., Przeździecka, D., Mieszczyński, T. (2007). Ewolucja polskich regulacji prawnych przeprowadzania doświadczeń na zwierzętach, [w:] M.Z. Felsmann, J. Szarek, M. Felsmann (red.), Dawna medycyna i weterynaria, s. 243-253, Chełm: Wyd. Muzeum Ziemi Chełmińskiej. ISBN 8391903745.

Bakuła, T., Lis, Ł. Ordoński, Z. (2011). Bezpieczeństwo w pracy lekarza weterynarii. Dobra Praktyka Weterynaryjna, „Życie Weterynaryjne”, tom 86 (4), s. 265-269. ISSN 0137-6810.

Boć, J. (2010). Kontrola prawna administracji, [w:] J. Boć (red.), Prawo administracyjne, s. 234-389, Wrocław:Wydawnictwo Kolonia Limited. ISBN 9788360631539.

Dobkowski, J. (2007). Pozycja prawnoustrojowa stużb, inspekcji i straży, s. 185, Warszawa: Wolters Kluwer. ISBN 8375260754.

Kwiatek, K., Kowalczyk, E. (2010). Wytyczne Kodeksu Żywnościowego w zakresie funkcjonowania analizy ryzyka $w$ bezpieczeństwie żywności do wdrożenia przez odpowiednie organy władzy państwowej, „Życie Weterynaryjne”, tom 85 (3), s. 246-249. ISSN 0137-6810. 
Jagielski, J. (2012). Rola administracji publicznej, s. 12, Warszawa: Wydawnictwo LexisNexis. ISBN 9788378063902.

Lang, J. (2015). Podstawowe pojęcia teoretyczne $w$ nauce prawa administracyjnego, [w:] M. Wierzbowski (red.), Prawo administracyjne, s. 35, Warszawa: Wydawnictwa Prawnicze PWN. ISBN 9788326484377.

Lisiowska, M., Markowska-Daniel, I., Związek, J. (2011). Wybrane regulacje prawne dotyczace zwalczana afrykańskiego pomoru świń, „Życie Weterynaryjne”, tom 86 (12), s. 946-948. ISSN 0137-6810.

Pejsak, Z. (2016). Laboratoryjna identyfikacja czynników etiologicznych chorób zakaźnych świń. „Życie Weterynaryjne”, tom 91 (7), s. 500-503. ISSN 0137-6810.

Pejsak, Z., Woźniakowski, G., Śmietanka, K., Ziętek-Barszcz, A., Bocian, Ł., Frant, M., Niemczuk, K. (2017). Przewidywany rozwój sytuacji epizootycznej w zakresie afrykańskiego pomoru świń w Polsce, „Życie Weterynaryjne”, tom 92, (4), s. 255-259. ISSN 0137-6810.

Rudy, M., Kapusta, M. (2005). Graniczna kontrola weterynaryjna - procedury administracyjne. Część I, „Życie Weterynaryjne”, tom 80 (8), s. 465. ISSN 0137-6810.

Rudy, M. (2013). Założenia do projektu ustawy o Państwowej Inspekcji Bezpieczeństwa Żywności i Weterynarii „Życie Weterynaryjne”, tom 88 (8), s. 613-614. ISSN 0137-6810.

Zimmermann J. (2016). Prawo administracyjne, Warszawa: Wydawnictwo Wolters Kluwer. ISBN: 9788380923362.

Związek, J. (2011). Aktualna sytuacja epizootyczna afrykańskiego pomoru świń oraz dane na temat jego zwalczania, „Życie Weterynaryjne”, tom 86 (10), s. 766-770. ISSN 0137-6810.

\section{Legal acts}

Rozporządzenie (WE) nr 178/2002 Parlamentu Europejskiego i Rady z dnia 28 stycznia 2002 roku ustanawiające ogólne zasady i wymagania prawa żywnościowego, powołujące Europejski Urząd ds. Bezpieczeństwa Żywności oraz ustanawiające procedury w zakresie bezpieczeństwa żywności, Dz.Urz.UE L 2002 Nr 31, str. 1.

Rozporządzenie Ministra Rolnictwa i Rozwoju Wsi z dnia 28 października 2004 r. w sprawie form współpracy organów Inspekcji Weterynaryjnej z Wojskową Inspekcją Weterynaryjną, Dz.U. Nr 245 poz. 2462. 
Rozporządzenie (WE) nr 882/2004 Parlamentu Europejskiego i Rady z dnia 29 kwietnia 2004 r. w sprawie kontroli urzędowych przeprowadzanych w celu sprawdzenia zgodności z prawem paszowym i żywnościowym oraz regułami dotyczącymi zdrowia zwierząt i dobrostanu zwierząt, Dz.Urz.UE L 2004 Nr 161, str. 1.

Rozporządzenie Ministra Rolnictwa i Rozwoju Wsi z dnia 27 stycznia 2015 r. w sprawie wprowadzenia programu zwalczania i monitorowania choroby Aujeszkyego u świń, Dz.U. z 2015 r. poz. 189.

Ustawa z 27 sierpnia 2003 r. o weterynaryjnej kontroli granicznej, tekst jednolity: Dz.U. z 2017 r. poz. 970.

Ustawa z dnia 29 stycznia 2004 r. o Inspekcji Weterynaryjnej, tekst jednolity: Dz.U. z 2016 r. poz.1077 ze zm.

Zarządzenie nr 1 Ministra Rolnictwa i Rozwoju Wsi z dnia 2 marca 2010 r. w sprawie organizacji wojewódzkich, powiatowych i granicznych inspektoratów weterynarii, Dz.Urz. MRiRW Nr 3, poz. 3.

\section{Case-law}

Orzeczenie Sądu Administracyjnego w Rzeszowie z dnia 17 grudnia 2014 r., sygn. akt. SA/Rz 865/13, http://www.prawoweterynaryjne.pl/artykuly/orzeczeniemsadu-administracyjnego-w-sprawie-uniemozliwienia-i-utrudnienia-urzedowejkontroli-weterynaryjnej/ [dostęp: 23.05.2017].

\section{Internet sources}

PRK-3 Procedura postępowania w czasie zagrożenia wystąpieniem lub wystąpienia choroby zakaźnej zwierząt (epizootie), Podlaski Urząd Wojewódzki, 2013, http:// www.powiatlomzynski.pl/plik.php?id=323 [dostęp 17.06.2017].

Projekt ustawy o Państwowej Inspekcji Bezpieczeństwa Żywności z dnia 13.07.2016 r. https://legislacja.rcl.gov.pl/projekt/12287605/katalog/12366694\#12366694 [dostęp 15.06.2017].

Raport NIK Działania organów administracji rządowej na rzecz bezpieczeństwa żywności nr ewid.: 46/2016/P/15/050/KRR, https://www.nik.gov.pl/kontrole/ $\mathrm{P} / 15 / 050 /$ [dostęp 17.06.2017].

Stanowisko Krajowej Rady Lekarsko-Weterynaryjnej z dnia 9 marca 2017 r. w sprawie projektu ustawy o Państwowej Inspekcji Bezpieczeństwa Żywności oraz ustawy Przepisy wprowadzające ustawę o Państwowej Inspekcji Bezpieczeństwa Żywności, http://www.vetpol.org.pl/ [dostęp 17.06.2017]. 